Revista Perspectiva Online: Humanas \& Sociais Aplicadas

Dezembro de 2017, Vol.7, n² 20, p.62-81

ISSN: 2236-8876 (Online)

DOI: $10.25242 / 887672020171195$

\title{
PERCEPÇÕES SOBRE O ACOLHIMENTO INSTITUCIONAL DE CRIANÇAS E ADOLESCENTES A PARTIR DE HISTÓRIAS DE VIDA
}

\author{
Paula Márcia Seabra de Sousa ${ }^{1}$, Luisa Maria Moreira Duarte Valentim Alberto ${ }^{2}$, Maria Clara \\ Crespo dos Santos $^{2}$ \& Patricia Constantino ${ }^{3}$
}

\begin{abstract}
RESUMO
SOUSA, P.M.S, ALBERTO, L.M.M.D.V., SANTOS, M.C.C., CONSTANTINO, P. Percepções Sobre O Acolhimento Institucional de Crianças e Adolescentes a Partir de Histórias de Vida. Perspectivas Online: Humanas \& Sociais Aplicadas, v.7, n.20, p.62-81, 2017.
\end{abstract}

O tema escolhido situa-se no âmbito da psicologia social e jurídica. Deseja-se lançar um olhar sobre as histórias de vida de pessoas que, em algum momento de suas vidas passaram pelo processo de acolhimento, fazendo uma articulação com a história social. O objetivo geral da pesquisa é construir junto aos entrevistados a trajetória de suas vidas antes, durante e depois da institucionalização e suas perspectivas para o futuro. A metodologia utilizada é a técnica qualitativa, utilizando o método de Histórias de Vida. Estimou-se que a partir dos discursos apresentados pelos sujeitos da pesquisa sobre suas histórias de vida antes, durante e depois da passagem por uma instituição de acolhimento, mediante escuta qualificada das pesquisadoras, tais sujeitos pudessem elaborar o que se passou em suas vidas, tornando essa trajetória visível a eles, abrindo espaços para construção de sonhos, caminhos e perspectivas para o futuro. Dessa forma, a pesquisa contribuiu para a formação de novos significados para os sujeitos da pesquisa, assim como para as pesquisadoras, no que diz respeito ao olhar em direção às pessoas que estão ou passaram por situação de acolhimento institucional e quanto ao próprio Acolhimento Institucional. Almejamos assim, que este trabalho possibilite a abertura de novas pesquisas, neste âmbito, valorizando o contexto institucional, em todos seus aspectos.

Palavras chaves: Acolhimento; Instituição; Psicologia; Sujeito. 


\begin{abstract}
The topic chosen is within the scope of social and legal psychology. We want to take a look at the life stories of people who, at some point in their lives, went through the sheltering process, articulating with social history. The general objective of the research is to build with the interviewees the trajectory of their lives before, during and after institutionalization and their perspectives for the future. The methodology used is the qualitative technique, using the method of Life Story interviewing. It was estimated that from the discourses presented by the individuals of the research about their life histories before,

researchers, such individuals could elaborate what happened in their lives, making this trajectory visible to them, opening spaces for the construction of dreams, paths and perspectives for the future. In this way, the research contributed to the formation of new meanings for the subjects of the research, as well as for the researchers, regarding the view towards the people who are or have been through an institutional shelter situation and the Institutional Shelter itself. We hope that this work allows the opening of new research, in this context, valuing the institutional context, in all its aspects.
\end{abstract} during and after the passage through a host institution, through qualified listening of the

Keywords: Shelter; Institution; Psychology; Individuals.

\footnotetext{
${ }^{1}$ Especialista Direito Civil e Processo Civil- Universidade Veiga de Almeida - UVA- Rua Ibituruna, 108 - Maracanã, RJ,CEP: 20271-020, Brasil;

${ }^{2}$ Graduada em Psicologia Institutos Superiores de Ensino do CENSA- ISECENSA - Rua Salvador Correa, 139, Centro, Campos dos Goytacazes, RJ, CEP: 28035-310, Brasil;

${ }^{3}$ Institutos Superiores de Ensino do CENSA - ISECENSA - Laboratório Violência e Instituições - Rua Salvador Correa, 139, Centro, Campos dos Goytacazes, RJ, CEP: 28035-310 - Fundação Oswaldo Cruz - FIOCRUZ - Escola Nacional de Saúde Pública, Departamento de Epidemiologia e Métodos Quantitativos em Saúde- Avenida Brasil, 4036, Manguinhos,CEP:21040361, Brasil.

(*)e-mail: paulamseabra@yahoo.com.br

Data de chegada: 24/05/2017 Aceito para publicação: 24/08/2017
}

Persp. online: hum. \& sociais aplicada., Campos dos Goytacazes, 20 (7), 62-81, 2017

seer.perspectivasonline.com.br 


\section{INTRODUÇÃO}

O tema escolhido situa-se no âmbito da psicologia social e jurídica. Deseja-se lançar um olhar sobre as histórias de vida de pessoas que, em algum momento de suas vidas, passaram pelo processo de acolhimento fazendo uma articulação com a história social.

Deve-se ter em mente que é dever da família, da sociedade e do Estado assegurar à criança e ao adolescente seus direitos fundamentais, à vida, à saúde, à alimentação, à educação, ao lazer, à profissionalização, à cultura, à dignidade, ao respeito, à liberdade e à convivência familiar e comunitária. Tais direitos foram reconhecidos na Convenção Internacional sobre os Direitos da Criança e incorporados pelo artigo 227 da CF/88 combinados com os artigos $3^{\circ}$ e $4^{\circ}$ do Estatuto da Criança e Adolescente de 1990.

Assim, a família, a sociedade e o Estado têm a obrigação de encontrar meios eficazes que protejam e viabilizem estes direitos fundamentais da criança e do adolescente. Amin (2011, p.35) afirma: "indispensável que todos os atores da área infanto-juvenil tenham claro para si que o destinatário final de sua atuação é a criança e o adolescente. Para eles é que se tem que trabalhar. É o direito deles que goza de proteção constitucional em primazia [...]".

Diante disso é claro perceber que instituições de acolhimento devem oferecer proteção, carinho e valores para a formação destas crianças e adolescentes. Não deve ser um sistema autoritário, com inúmeras regras burocráticas ou, simplesmente, estar à margem da sociedade. Caso contrário estaria o próprio sistema de proteção e abrigo violentando o direito dessas crianças e adolescentes, porém com o agravante desses sujeitos estarem fora do contexto social de origem, longe de seus amigos, conhecidos, etc.

Importante ressaltar que essas crianças e adolescentes foram abrigados em um sistema de proteção, por não terem encontrado alternativa diferente a do acolhimento que pudesse ajudá-los a enfrentar uma dificuldade concreta de vulnerabilidade social, negligência e/ou qualquer tipo de violência que fira a dignidade humana. Por esse motivo, não se deve afastar estas crianças e adolescentes da sociedade, caso contrário se estaria praticando um ato de violência social, deixando esses meninos e meninas à margem da sociedade, aumentando o quadro dos invisíveis sociais. Eles devem estar inseridos na comunidade.

O presente trabalho tem como objetivo geral construir junto aos entrevistados a trajetória de suas vidas antes, durante e depois da institucionalização e suas perspectivas para o futuro, articulando-a com a trajetória social. O que se busca com essa pesquisa é identificar as diferenças na percepção sobre o processo de institucionalização; avaliar os fatores positivos e negativos da institucionalização; identificar as perspectivas dos sujeitos para o futuro, após a institucionalização.

Importante ressaltar que abrindo espaço de escuta para essas pessoas relatarem suas histórias, a partir do seu próprio ponto de vista, abre-se espaço para encontros, construções de sentidos e ressignificações. A relevância acadêmica deste estudo situa-se na produção de um estudo que proporcione novos conhecimentos voltados para vivências de pessoas que passaram pelo processo de institucionalização, a partir do método histórias de vida, com sujeitos que foram institucionalizados. É importante levar em consideração os pensamentos e sentimentos desses sujeitos em relação ao sistema institucional, inclusive, para entender como esse mecanismo funciona e se está cumprindo com os seus objetivos. Possibilita, também, novas produções de conhecimento do contexto institucional a partir do olhar de quem nele viveu.

Em 13 de Julho de 1990 foi publicada a Lei $n^{0} 8.069$ - Estatuto da Criança e do Adolescente - que revogou a Lei n 6.697 - Código de Menores. A doutrina da "situação irregular" do menor, nesse momento, foi substituída pela doutrina da "proteção integral" à criança e ao adolescente, amparada pelo ECA em seu artigo $1^{\circ}$ "Esta Lei dispõe sobre a proteção integral à criança e ao adolescente". Nesse momento, pode-se perceber o início da mudança de paradigmas, com a troca da terminologia estigmatizante "Menor" para "Criança e Adolescente", expressão também utilizada pela Constituição da República de 1988 e pelos documentos internacionais. 
Pode-se destacar a criação do Conselho Nacional dos Direitos da Criança e do Adolescente, CONANDA, pela Lei ${ }^{\circ} 8.242$ de 1991, órgão de âmbito federal responsável pela efetividade dos direitos, princípios e diretrizes estabelecidos no ECA. A publicação da Lei Orgânica de Assistência Social (Loas, Lei $n^{\circ} 8.742$ de 1993), que criou o Conselho Nacional de Assistência Social (CNAS) e a Política Nacional de Assistência Social (Pnas) aprovada em 2004, que apresenta as diretrizes para a efetivação da assistência social como direito de cidadania e responsabilidade do Estado.

Com essas legislações em vigor foi possível o surgimento de novas instituições, como: o Conselho Municipal dos Direitos da Criança e do Adolescente - CMDCA, dos Conselhos Tutelares, as equipes interdisciplinares dos Fóruns, o Centro de Referência de Assistência Social - Cras, o Centro de Referência Especializado de Assistência Social - Creas. A Lei $\mathrm{n}^{\circ} 12.010$ de 2009 instituiu a expressão acolhimento institucional, que também foi adotada nas Orientações Técnicas para Serviços de Acolhimento para Crianças e Adolescentes (CNAS/CONANDA, 2009).

Contudo, o amparo legal não é suficiente para proteger essas pessoas. É preciso trazer para a realidade aquilo que está escrito. Fazer com que o ideal se aproxime do real. Não se deve esquecer que as crianças e os adolescentes institucionalizados também são sujeitos de direito e que estão amplamente amparados pelo ECA, não existindo exclusão.

Visando a aproximação da prática com as normas, mais recentemente foi publicado o documento Orientações Técnicas: Serviços de Acolhimento para Crianças e Adolescentes (CNAS/CONANDA, 2009) com o objetivo de aprimorar os serviços de acolhimento institucional. Esse documento trouxe princípios e metodologias a serem aplicados nas diferentes modalidades de serviço de acolhimento.

Precisamos entender que essas pessoas vêm de mundos diferentes, tem conceitos diferentes, viviam em regiões diferentes, em comunidades diferentes e de uma hora para a outra se veem em um mesmo ambiente, com regras nunca vividas antes. Deve-se, diante dessa realidade, tentar integralizar essas pessoas ao novo ambiente em que estão sendo inseridos, para que este convívio seja o menos agressivo possível.

Deve-se lembrar que "o princípio nuclear da ética é o respeito ao outro. E, para respeitar o outro, é preciso que se admita que ele existe, que se reconheça a existência dele" (BAPTISTA, 2006, p.15). Trabalhar com crianças e adolescentes institucionalizados, abrindo espaços para ouvi-los, é acima de tudo reconhecer a existência de cada um como ser humano, com direitos, deveres e dignidade. Isso é ética.

\section{METODOLOGIA}

Foi realizada pesquisa de campo usando a técnica qualitativa, utilizando o método de Histórias de Vida, a partir da seguinte indagação: "Conte-me sua história". O objetivo dessa metodologia é tentar alcançar uma compreensão mais ampla das percepções desses sujeitos, que foram atravessados em algum momento de sua história pelo processo de acolhimento. Para alcançar a meta dessa pesquisa entrevistamos 3 (três) adultos, sendo 1 (um) do sexo feminino e 2 (dois) do sexo masculino com idade entre 18 a 25 anos. O projeto foi submetido ao comitê de Ética do Isecensa e aprovado através do número 1.596.544.

Segundo Silva, Barros, Nogueira \& Barros (2007): “O método de História de Vida é um método científico com toda força, validade e credibilidade de qualquer outro método, sobretudo porque revela que por mais individual que seja uma história, ela é sempre, ainda, coletiva, mostrando também o quão genérica é a trajetória do ser humano" (p.33-34).

O método história de vida tem como proposta o desenvolvimento de uma escuta qualificada, participativa e comprometida com o sujeito pesquisado. Nesse encontro de partilha e engajamento, amparado por uma postura ética e coerente, a relação de confiança é estabelecida. Abre possibilidades para que aqueles que relatam suas histórias, repletas de experiências, sentimentos e emoções, possam ressignificá-las, 
refletindo sobre o passado, presente e futuro, dando continuidade a suas histórias diante dos relatos apresentados.

A história de vida é um recurso muito utilizado pelas Ciências Sociais e é definida por Minayo "como uma entrevista prolongada com interação entre pesquisador e informante, combinando observação, relatos introspectivos de lembranças relevantes e roteiros mais ou menos centrados em algum tema". (CONTE; SILVEIRA; TOROSSIAN \& MINAYO, 2014, p.769).

A partir dessa metodologia buscou-se construir junto aos entrevistados a trajetória de suas vidas antes, durante e depois da institucionalização e suas perspectivas para o futuro. Assim como identificar e avaliar os fatores positivos e negativos da institucionalização; identificar as perspectivas dos sujeitos para 0 futuro, após a institucionalização; e analisar a trajetória pessoal do sujeito entrevistado articulando-a com a trajetória social.

As entrevistas foram gravadas, transcritas e, posteriormente, analisadas pela técnica da análise de conteúdos. O Termo de Consentimento Livre e Esclarecido foi assinado pelos sujeitos envolvidos nesse estudo, seguindo em anexo. Os critérios de exclusão utilizados na pesquisa foram pessoas maiores de 25 (vinte e cinco) anos e menores de 18 (dezoito) anos; como também qualquer sujeito que não tenha aceitado assinar o Termo de Consentimento Livre e Esclarecido.

\section{RESULTADOS}

Como resultado, apresentamos os relatos das seguintes histórias de vida:

\subsection{Vitória}

Vitória tem 23 anos de idade, atualmente, mora em Campos dos Goytacazes, trabalha no comércio e tem uma filha de quase quatro anos de idade.

\section{Antes da institucionalização:}

Relatou que foi para a instituição de abrigamento muito nova com, aproximadamente, um ano de idade e não se lembra dos acontecimentos de sua vida antes desse período.

\section{Durante a institucionalização:}

Já no acolhimento, disse conseguir recordar os fatos a partir dos seis anos de idade. A primeira coisa mencionada foi a quantidade de crianças existentes no abrigo na época, verbalizando que eram muitas crianças e que tinham horário para tudo. Relatou também que até a quarta série o estudo era dentro do próprio abrigo, ressaltando que após esse período as crianças iam estudar em uma escola em Barra de Itabapoana (localidade próxima). Salientou que os passeios da instituição eram feitos nas férias, onde conheciam muitos lugares diferentes, e durante o ano, nos fins de semana, iam à praia. Tem poucas lembranças das visitas da sua mãe biológica, contudo, lembra-se de uma vez que sua mãe solicitou a sua guarda e o juiz a questionou se gostaria de morar com sua genitora, tendo ela não aceitado, verbalizando que a mãe era uma pessoa "estranha", pois não a conhecia, nem tinha nenhum vínculo afetivo. Após tal situação a mãe chorou muito. Descobriu ter cinco irmãos, uma morava na instituição com ela e os outros com outros familiares, fato este que virou questão central na sua vida, pois gostaria de entender o motivo pelo qual apenas ela e a irmã haviam ido para a instituição. Enfatizou que, mesmo estando em contato com a irmã que morava no mesmo abrigo, não havia aproximação entre ambas.

Verbalizou que não havia motivos para reclamar da instituição, pois era "tudo certinho". Disse nunca ter precisado fazer os serviços domésticos. Sempre tinha um funcionário para as funções. Enfatizou que apenas lavavam as louças como forma de aprender e contribuir com as tarefas e que havia bastante meninas para o revezamento. Sobre os meninos, informou ter uma certa divisão entre as tarefas, sendo estes 
encarregados mais comumente dos trabalhos rurais. Relatou que a "Dona do abrigo" contou que quando ela chegou ainda muito pequenininha, por volta de 1995, cantava para pedir comida, como se estivesse repetindo um gesto de quando vivia com sua mãe. Por isso, a "Dona do abrigo" dizia para ela que não precisava cantar para conseguir comida.

Ressaltou que na instituição foi onde "aprendeu tudo". Disse que lá os namoros eram às escondidas, pois não podiam acontecer e que seu primeiro namorado foi de lá. Salientou que os funcionários eram todos muito bons. Existiam governanta, professora, costureira, cozinheira, babás, etc. Enfatizou que se for lá hoje em dia sabe onde fica cada coisa e que tem lembranças muito boas. Sobre o psicólogo, informou que não se lembra de ter tido nenhum na instituição, lembrando apenas de uma assistente social que sempre conversava com eles, procurando saber se estava acontecendo alguma coisa e o motivo para tentativas de fuga.

Relatou sobre as tentativas de fuga do abrigo, que começaram por volta dos seus 12 anos de idade e que eram motivadas pela curiosidade sobre suas origens. Vitória verbalizou que ela e as outras meninas que tentavam fugir não conseguiam ir muito longe, pois não conheciam lugar nenhum. Os episódios de fuga eram, na verdade, aventuras que viviam. Demonstrou se divertir com tal situação, mas que sempre ao retornar para a instituição levavam um "castigo" e que esses consistiam, basicamente, em proibir as coisas de lazer durante uma ou duas semanas, como a televisão, dormir tarde, etc. Devido à quantidade de fugas, o juiz deu a guarda tanto dela quanto da irmã para a mãe, época em que tinha mais ou menos 14 anos de idade.

\section{Após a institucionalização}

Esse período foi bastante conturbado, verbalizando que havia muitas brigas no ambiente em que passaram a viver e que não se dava bem com o padrasto. Quis saber o motivo da mãe não ter permanecido com ela e com a irmã, verbalizando que a argumentação de que "ela não tinha condições e passava necessidade", "não tinha emprego", foi aceita por certo tempo. Mas tais argumentos foram fracos e nunca a convenceram, porque hoje ela é mãe e sabe que não é assim. Disse que "tudo bem, se a mãe não tivesse feito isso, talvez ela morresse de fome", mas "Por que não entregar para uma família?" e afirmou que, hoje, ela tem uma filha e sabe que faria qualquer coisa por ela.

Vitória contou que neste período de convivência familiar sofreu uma tentativa de abuso por uma pessoa bem próxima da família e que, após esse episódio, decidiu "fugir" e "ir para onde a vida a levasse". Foi para Travessão de Barra, onde conheceu o seu "anjinho da guarda", sua melhor amiga, a qual considera como uma irmã até os dias atuais. Enfatizou não ter esse vínculo forte nem com sua própria irmã. Relatou que neste período foi acolhida por essa amiga que residia com sua avó. Ocorre que essa avó nunca gostou dela e falava que ela parecia com "um molequinho de rua". A entrevistada concordou com essa descrição. Por isso, Vitória se escondia na casa de sua amiga para dormir e comer, sem que essa avó soubesse da sua presença, assim, ficava durante o dia na rua e só ia para a casa bem tarde da noite. No quintal havia uma casa vazia que não tinha luz e era lá que Vitória dormia e ficava escondida. Salientou que passou um tempo vivendo dessa maneira até quando conseguiu o primeiro emprego em uma pizzaria e saiu da casa da amiga, lembrando que a avó da amiga nunca soube de sua presença por lá.

Vitória verbalizou que gostava muito de trabalhar na pizzaria, que lá não recebia muito, mas que os patrões auxiliavam com alimentação e moradia e a tratavam como a própria filha deles, mas salientou que com medo do Conselho Tutelar a "pegar", resolveu ir para o Espírito Santo, onde trabalhou numa Pizzaria que era dos mesmos donos. Neste meio tempo o seu "anjinho da guarda" foi morar com a mãe em Macaé e a convidou para morar com elas. Aceitou o convite. Ressaltou que não conseguiu terminar os estudos, pois ainda era menor de idade e precisaria da assinatura de algum responsável legal. Sendo assim, teve que aguardar completar a maioridade. Salientou o seu desejo de conseguir terminar os estudos na época, verbalizando que a primeira coisa que fez após completar os dezoito anos foi procurar uma escola para concluir o ensino médio.

Na mesma cidade conheceu um rapaz que passou a namorar. Após certo tempo passou também a residir com ele e com sua família. Contou que neste momento se apegou bastante a sogra, considerando-a 
uma mãe, alguém que passou a conhecer toda sua história e a se preocupar com ela como filha. Enfatizou que a relação das duas é bastante forte até hoje, e a considera sua verdadeira mãe. É agradecida a todos que passaram por seu caminho e ajudaram de alguma forma, mas que para ela as pessoas mais especiais de sua vida são essa "mãe" e sua amiga. Verbalizou ainda que mesmo terminando o tal namoro, continuou residindo em sua casa e sendo tratada como filha.

Relatou um episódio bem marcante de sua história, quando já namorando outro rapaz, viajou para Farol de São Thomé no verão e que ficou em uma casa com alguns amigos e o namorado, e que lá inventaram de fazer "macarrão na churrasqueira", e que por conta disso sofreu um acidente. Contou que ao acenderem a churrasqueira o fogo foi em sua direção e seu corpo começou a pegar fogo, até que alguém jogou um balde d'agua nela. Enfatizou ter visto fumaça saindo de si e que sua roupa estava completamente colada no corpo como uma borracha. Foi levada para o Hospital Ferreira Machado e ficou lá, internada, por três meses até sua recuperação. Relatou também que a sua mãe afetiva, foi quem ficou no hospital e a visitou várias vezes, enfatizando que sua mãe biológica foi apenas uma vez visitá-la e, mesmo assim, não ficou junto dela no momento da visita. Ao retornar para Macaé, após ter saído do hospital, descobriu que estava grávida do namorado. Por diversas vezes na entrevista declarou ser o pai da sua filha alguém muito especial. Neste período encontrou dificuldades para contar a "mãe" sobre sua gravidez, com medo de decepcioná-la e de perder todo afeto e amor, como se estivesse correndo o risco de perder a mãe que havia conquistado. Porém, recebeu um retorno bastante positivo desta pessoa, que continuou a apoiá-la como filha.

Relatou que se mudou para Campos e passou a residir com o pai da sua filha, mas descobriu que este a traiu no período da gravidez. Mesmo não tendo continuado o relacionamento, continuou a residir em sua casa a pedido dele para esperar a filha crescer um pouquinho, pois tinha medo dela esquecê-lo. Desta forma, a entrevistada permaneceu até os seis meses da filha em Campos, tendo depois retornado a Macaé. Contou que o pai da criança ia todos finais de semana ver e buscar a filha. Ela sempre fez questão de que a mesma tivesse esse contato, assim como, com o restante da família por saber a falta que uma família faz. Após certo tempo resolveu retornar para Campos, para que sua filha pudesse ter maior contato com o pai e seus familiares, salientando o quão importante é proporcionar essa vida familiar para a filha.

Disse que sempre teve muita curiosidade em saber quem era seu pai. Em Campos, começou a procurá-lo a partir de alguns fatos que sabia e apenas com o primeiro nome do seu pai, conseguiu, após um tempo de procura, encontrá-lo. A princípio, os dois tiveram um bom relacionamento, tendo, inclusive, sido uma emoção muito grande para ambos o encontro e começaram a ter uma maior intimidade e aproximação. Contudo, este pai já tinha outra família, que não a aceitou, dando início a um conflito familiar, principalmente com a esposa do pai. Relatou que a família do pai começou a dizer que ela não era sua filha e que deveria fazer um teste de DNA, porém a mesma não aceitou tal imposição, pois seu próprio pai havia dito que ela era sua filha, entendendo que por isso não precisaria provar para os outros. Verbalizou ter dado ao pai a oportunidade de ter uma filha, assim como a ela mesma a oportunidade de ter um pai, mas este pediu na justiça que ela fizesse o exame de DNA e ela não quis. Ficou extremamente chateada, dizendo que "não iria fazer, porque agora quem não queria que ele fosse meu pai era eu". Afirmou que se já viveu sem pai esse tempo todo, não faria diferença, mesmo sabendo que faz.

Vitória contou que quando foi a Cabo Frio para um aniversário, aproveitou para marcar um encontro com uma das meninas que havia morado com ela na instituição. Deixou sua filha com a tia e foi esperar por sua amiga em uma rodovia. Neste lugar não havia área para celular e já estava escurecendo. No momento em que estava aguardando, passou um cara em uma moto e mandou que ela subisse apontando uma arma para ela. Naquele momento começou a chorar, pois acreditava que iria morrer. O cara a levou para uma ruazinha deserta e a estuprou. Nesse momento, a entrevistada se emocionou bastante. Ressaltou que nunca esqueceu a placa da moto, imagem marcada em sua memória. Contou sobre o ocorrido apenas para sua melhor amiga, mas que sua mãe por afetividade percebeu que algo estava errado, então começou a indagá-la se havia acontecido alguma coisa. Nesse momento, revelou tudo para sua mãe que a levou para o hospital para fazer exames. Tomou um coquetel de remédios e foi registrar o ocorrido na delegacia. Dias depois, recebeu um telefonema da delegacia de Cabo Frio, pedindo que ela comparecesse, pois havia um suspeito. Vitória disse ter ido à delegacia, pois queria se vingar do cara e que fosse preso pelo que fez. A polícia armou um 
flagrante para prender o suspeito. Sendo assim a mesma marcou um encontro com o cara, orientada pelos policiais. Relatou que quando o mesmo a viu, logo a reconheceu e tentou fugir, mas os policiais o pegaram e ele está preso até hoje. Ressaltou ainda que entra sempre no facebook do filho do cara, pois apesar de achar que ele deve pagar pelo crime que cometeu, fica triste por ver que o seu filho está crescendo com uma revolta e sem pai.

Sobre seus sonhos e planos futuros, verbalizou que sempre quis ser enfermeira, mas que devido a falta de condições financeiras não conseguiu ainda fazer essa faculdade. Tem o desejo de ir para África, "tipo o médico sem fronteiras". Atualmente, está trabalhando e reside em uma casa alugada. Apesar de não gostar muito de Campos, está aqui para que a filha fique perto da família, principalmente da avó, com a qual ela é muito apegada, "um chicletinho". Sobre o instituto relatou que já faz um tempo que não vai lá, mas que foi no ano anterior levando a filha, para mostrar à mesma onde a mãe viveu. Disse que procura ter contato com todos que viveram lá, mas que tem maior aproximação com aquelas que eram mais próximas dela. Entende não ter nenhum ponto negativo para falar da instituição, dizendo, inclusive, ter se arrependido um pouco de ter saído de lá, porque tem amigos que cresceram, estudaram, fizeram faculdade e tiveram a oportunidade de ter um futuro melhor, pois era o que a "Dona do orfanato" tinha guardado para ela também. Salientou não se arrepender de tudo que passou, mas que poderia ter aproveitado aquela oportunidade. Mas sente que o que viveu trouxe consequências boas, uma delas é a sua filha. E referindo-se a sua mãe biológica, afirmou: "ela estragou minha vida, assim, pela parte do carinho que eu tinha ela não estragou tanto, ela me privou, mas também, pelo que eu vi, não privou tanto".

Vitória ressaltou que sente falta sim da família, apesar de ter sua mãe por afetividade, o pai da sua filha, que é alguém muito presente, e a amiga que é uma irmã para ela. Mas, mesmo assim, sente falta de uma família, daquela de origem. Verbalizou que "tirou bastante coisa de tudo que passou", referindo-se às lições de sua vida. Diferentemente de sua irmã biológica, que tem seis filhos e não tem condições de criá-los, assim como sua mãe biológica. Por fim, disse que sua mãe biológica vem passando necessidades e que ela mesma, apesar de tudo, tem vontade de ajudar, mas também não tem condições.

\section{Síntese analítica}

O período anterior à institucionalização não se apresentou significativo para a entrevistada. Durante a institucionalização demonstrou ter criado vínculos afetivos, sentindo-se em um ambiente acolhedor, onde fez amizades, estabeleceu laços, considerando aquele espaço muito bom para ela, pelo qual possui um sentimento de gratidão. No entanto, desejava ir em busca de suas raízes biológicas, porque, nesse período, muitas dúvidas surgiram: queria saber sobre suas origens, o real motivo de ter sido acolhida, enquanto parte dos irmãos não havia ido para nenhuma instituição, caracterizando um sentimento de rejeição e uma curiosidade em saber o por quê. Após a institucionalização muitas coisas aconteceram, sendo relatadas muitas dificuldades no percurso. Demonstrou grande apego a uma amiga que a ajudou nesse período, sendo marcante em sua vida a presença desta pessoa. Também cabe citar que a entrevistada, apesar de todas as dificuldades, demonstrou-se extremamente determinada e encorajada, além de ser alguém que se reconhece tanto em seus aspectos positivos quanto negativos, e que faz dos problemas mola propulsora para seu crescimento, demonstrando o quão resiliente é.

\subsection{Gabriel}

Gabriel tem 19 anos de idade, mora em Campos dos Goytacazes em uma república com amigos, trabalha em uma lanchonete e se considera uma pessoa com dificuldades de expor seus sentimentos. Afirmou que enfrentou muitas dificuldades e conflitos em sua vida, mas que aprendeu que na vida "a gente tem que batalhar", para superar os desafios.

\section{Antes da institucionalização}

O entrevistado não se lembra da sua vida antes da institucionalização, pois foi para lá muito novo, por volta dos dois anos de idade. Apesar de não se lembrar dos seus pais descobriu, ainda na adolescência, 
que seus pais foram assassinados por algum tipo de conflito familiar, porém não nos relatou o motivo. Soube também que após o assassinato de seus pais, foi entregue a familiares para ser cuidado, mas praticamente nenhum deles aceitou ficar com a responsabilidade de criá-lo. Uma avó tentou pegar a sua guarda, mas esta foi negada pela justiça, por causa da saúde delicada da pretendente. Então, ele foi entregue pelos parentes a uma senhora que morava em São Francisco. No entanto, não tendo condições de criá-lo, essa senhora o entregou em uma instituição de acolhimento e, posteriormente, foi trabalhar nessa casa que o abrigou com o objetivo de ficar mais próxima dele, por causa do vínculo que se formou entre ambos.

\section{Durante a institucionalização}

Gabriel passou a morar na instituição de acolhimento entre os anos de 2000 e 2001 e foi adotado pela diretora do instituto. A sua mãe tem 16 filhos, sendo 4 biológicos e 12 adotados. Considera ter três mães: a mãe que o adotou, a mãe que o levou para a instituição e que participou de toda sua criação e a mãe que foi a sua babá nesse lugar.

Lembra que quando os meninos brigavam uns com os outros a sua mãe logo chegava, conversava com eles e colocava de castigo "de cara para a parede" ou quando pegava os meninos fazendo guerra de sapato no quarto de madrugada, colocava todo mundo no pátio também "de cara para a parede". Relatou que agradece por tudo isso que ela fez e completa dizendo: "acho que foi tudo isso que me tornou o que eu sou hoje". Considerava aqueles que ali viviam a sua família afirmando que "independente de serem pessoas que não têm o meu sangue é uma família, um cuida do outro, um ajuda o outro" com trocas de experiências e de histórias de vida, pois eram dores semelhantes.

Revelou que em São Francisco do Itabapoana as pessoas chamavam aquela instituição de orfanato e isso era um fato de muitos problemas para ele. A palavra orfanato "pesa muito". Sentia o preconceito das pessoas e não gostava de ir à escola por causa disso. Diziam: "ah, chegaram as crianças do orfanato", os "órfãos", por essa razão, muitas vezes, mentiu para sua mãe dizendo que estava doente para não ir à escola e não passar por esses constrangimentos. Lembrou que uma vez, em uma briga na escola, um menino o chamou de "filho da (...)" e isso o fez parar para se questionar sobre a possibilidade daquele xingamento ser verdade ou mentira.

Começou a querer saber a sua origem mais ou menos aos 12 anos de idade. Afirmou que isso era uma curiosidade de todos lá dentro e também uma dor. No entanto, quando descobriu a verdade sobre sua família biológica, ficou sem saber como lidar com aquela realidade e chegou a pensar que seria melhor não ter descoberto. Também descobriu que tem uma irmã, hoje com 18 anos, que mora no Rio de Janeiro e que foi adotada logo que nasceu. Sabe que tem parentes em Marataízes, um primo com quem mantém um pouco de contato, e parentes em São Francisco também, mas não procura muito por eles. Relatou que é muito difícil essa relação e que eles também não o procuram, não ligam... A única pessoa de quem ele gosta mesmo é da sua avó de 99 anos, pois sabe que ela tentou adotá-lo, por isso sempre vai visitá-la e pedir a bênção.

Gabriel lembra que no acolhimento cada um tinha o seu armário, com suas coisas, roupas, objetos pessoais. Que muitas pessoas doavam roupas para lá, inclusive, lojas doavam roupas novas, mas também havia costureira lá dentro que fazia roupas para eles. Os quartos eram separados por um corredor, de um lado meninas e do outro meninos e havia em média uns 20 adolescentes no quarto, o que motivava as guerras de sapatos ou outras brincadeiras na hora de dormir.

Por causa dos preconceitos que sofria fora dos muros da instituição, Gabriel não gostava tanto de sair de casa, a não ser ir à praia, pois se sentia protegido dentro da sua casa. Protegido "do mundo, do preconceito" e declarou que, por essa razão talvez, muitas vezes hoje em dia, se sente "solitário" e desprotegido. $\mathrm{O}$ entrevistado relatou que nunca tentou fugir do abrigo e justificou esse fato por ter ido muito pequeno para lá e, por isso, se acostumou com a rotina da casa. No entanto, lembra que algumas crianças tentavam fugir, não pelo lugar, pois gostavam de lá, mas porque não eram acostumadas com as regras. Dentro dessa instituição de acolhimento tinha horário para tudo: para estudar, para fazer o dever de casa, para comer, para dormir, para o lazer... E também havia a cobrança de notas, de comportamento, como 
também as consequências pelo mau comportamento, como ficar sem internet, dormir cedo se tirasse nota vermelha, não ir à praia... Correções disciplinares dessa maneira eram comuns lá dentro.

Revelou que no acolhimento era proibido namoro, pois a sua mãe tinha medo de um jovem engravidar o outro lá dentro, o que ocasionaria muitas complicações para ela. Todavia, sempre existiu um "ficar". Disse que ele nunca namorou, mas quanto ao "ficar" preferiu não se aprofundar nesse aspecto. A sua mãe, diretora da instituição, conversava abertamente com todos os jovens sobre sexualidade.

Relatou que as crianças e jovens saíam bastante para passear, mas nunca sozinhos. Relatou que, por ter sido adotado, podia sair sozinho, pois a responsabilidade sobre ele era inteiramente da sua mãe. No entanto, lembra de que quando ele saía sozinho, sua mãe sempre pedia para levar algum jovem com ele que estava abrigado na instituição. E que quando saía com os cuidadores ia todo mundo. Os aniversários eram sempre comemorados, mas a partir da sua adolescência passou a não gostar mais de comemorar aniversários, nem de datas comemorativas como Natal. Para ele todos os dias são os mesmos.

Quanto à figura paterna, Gabriel revelou que sentiu muita falta de ter um pai para conversar, principalmente, sobre assuntos sobre os quais não se sentia confortável em conversar com sua mãe. Apesar de ter tido um pai adotivo, o marido da sua mãe, que era holandês, não teve um relacionamento muito bom com ele. Achava que ele dava mais atenção ao primeiro filho que adotou e que, por disso, os dois brigavam bastante. Essa foi a parte mais difícil para o entrevistado, chegando a se emocionar.

Relatou que alguns boatos mentirosos surgiram sobre o instituto, como a existência de tráfico de crianças e de órgãos, porém todos falsos. Afirmou que diante disso pode-se perceber o preconceito que pessoas tinham para com eles. Também lembrou que em São Francisco havia navios que ficavam na beira da praia e que as pessoas diziam que eram da Holanda e que estavam ali para pegar as crianças do instituto. Esses boatos eram um grande problema para eles. Gabriel revelou que algumas crianças foram adotadas por pessoas estrangeiras e que, inclusive, ele mantém contato com alguns desses jovens que vivem no exterior e que, por isso, sabe que estão bem. Aprendeu a falar inglês e espanhol com seu pai e sempre quando chegava algum estrangeiro na instituição ele gostava de conversar.

Com relação à presença de psicólogos na instituição, Gabriel não tem lembranças boas e disse serem muito chatos, que as conversas eram horríveis, pois eles achavam que o "sujeito era obrigado a falar com eles, a conversar". Ele não se sentia a vontade na presença dos psicólogos, reclamando da forma de abordagem com muitas perguntas e pouca aproximação pessoal. Entendia que o trabalho do psicólogo era de "perguntar e passar para o juiz" o que era dito. Achava que eles prejudicavam suas vidas, afirmando: "sempre tive o pensamento que eles estavam lá para prejudicar e pronto".

\section{Depois da institucionalização}

Hoje o Gabriel admira muito sua mãe "adotiva", afirmando que ela é guerreira e foi muito importante em sua criação. Lembra-se das vezes que conversava com ele, brigava, colocava de castigo, das conversas sobre sexualidade, momento em que ficava com vergonha dela e falava que já estava bom, que já sabia... Enfim, é agradecido por essa vivência e lembra-se de tudo com carinho. Gabriel demonstrou ter um forte vínculo com a sua mãe e relatou que sempre vai a São Francisco visitá-la e ajudar a cuidar das crianças que estão lá.

No momento, diz ficar um pouco triste quando vai à instituição, pois já não tem tantas crianças. Acha que a prefeitura está querendo fechar esse espaço, criando muitos problemas, e que vê a sua mãe muito cansada lutando contra tudo isso. O seu maior sonho era de dar continuidade ao trabalho da sua mãe, mas entende não ser possível porque acha que a prefeitura não tem interesse em manter aquele espaço, a "casa", a "família", porque "eles querem fechar para esquecer aquilo, dizer é menos um problema aqui para a gente".

Gabriel quer fazer faculdade de Educação Física, já começou, mas parou e disse que tem dificuldade de dar continuidade às coisas. Também tem vontade de fazer concurso para Bombeiro, pois começou a 
trabalhar como salva-vidas com 16 anos e gostaria de "seguir carreira". Foi com o dinheiro que juntou como salva-vidas que conseguiu vir para Campos aos 18 anos de idade.

Afirmou que quer "ser alguém na vida", "ter nome", "ter reconhecimento", argumentando que a sociedade os considera "monstros", sem ao menos saber o que eles passaram na vida, sem saber os seus sentimentos, as suas histórias e já os julgam. Revelou que muita gente achava que ele seria um "drogado", que iria "roubar", "matar". Por essa razão, ele entende ser uma prova de que as pessoas estão erradas e que, na verdade, elas são preconceituosas. Com orgulho ressaltou que a sua mãe disse que o admira. O recado que quis deixar para a sociedade, além da sua história de vida, foi: "valorize teus pais, é o principal, independente de discussão, brigas, valorize, porque quando se perde, eu costumo dizer, que você perdeu a sua vida inteira".

\section{Síntese analítica}

Em relação a sua vida antes da institucionalização apesar do entrevistado não se lembrar de sua história, ficou nítido que existe um significativo sentimento de rejeição com relação aos seus familiares, assim como uma fragilidade nos vínculos afetivos devido ao contexto de violência, pois o assassinato dos seus pais foi fator preponderante para a condução ao abrigo. Já no período da institucionalização, demonstrou ter uma maior referência familiar em relação ao abrigo, pois na verdade ele foi adotado pela diretora que lá morava. Apesar da adoção, durante a sua adolescencia até completar 18 anos, nunca deixou de morar no acolhimento, como acolhido. Inclusive, sofreu com os estigmas colocados sobre as crianças e adolescentes institucionalizados, chegando a citar que a única coisa que mudaria era o nome "orfanato". Em relação à dinâmica da casa ele não encontra pontos negativos, mas defende com "unhas e dentes" aquele espaço, vendo como algo positivo ter muitas crianças, sendo uma questão de identificação. Uma coisa marcante foi à busca por sua história familiar, demonstrando muita resistência, conflitos e dor sobre o assunto. Após a institucionalização, ficou marcado um grande desejo de ser alguém, ser reconhecido e mostrar para as pessoas que iria vencer na vida, lutando contra o estigma de ter vivido em um "orfanato". Demonstrou ter grande gratidão pela instituição e pela mãe adotiva.

\subsection{Davi}

Davi tem 19 anos, mora em Campos dos Goytacazes, sozinho e trabalha no Ministério Público.

\section{Antes da institucionalização}

Relatou ter entrado no abrigo aos 9 anos de idade, por volta do ano de 2006, e se recorda que a institucionalização foi devido à violência sexual do genitor para com suas irmãs, sendo que todos os seus irmãos foram acolhidos. Informou não se lembrar da dinâmica familiar antes do primeiro abrigo no qual foi acolhido, no qual permaneceu durante seis anos, dos nove aos quinze anos de idade.

\section{Durante a institucionalização}

Neste período e aos quinze anos de idade, no entanto, ele e os irmãos passaram por um processo de adoção (neste momento ato falho "doação"), com uma família do Rio de Janeiro, que se interessou por adotar todo o seu grupo de irmãos. Explanou que a família era boa, mas que era rígida, no sentido de ter regras, que acha que o abrigo o acostumou mal, por ter tudo na mão, e que na família não era assim, cada um tinha que auxiliar, então que antes de terminar o período de adaptação pediu para voltar para a instituição, ele e sua irmã, que atualmente está acolhida.

Quanto ao tempo que passou na primeira instituição, disse que foi muito bom, que ele passou a valorizar os estudos, tinha suporte psicológico e pedagógico, acreditando ter sido fundamental para seu crescimento educacional. Disse que tinha uma grande afinidade com a coordenadora e só respeitava a esta. Chegavam até a falar que ele era paparicado por ela, mas que ela sempre o corrigia e ensinava. Mencionou 
sobre a psicóloga, que dizia que a coordenadora sempre passava a mão em sua cabeça, e que por isso que ele se comportava como reizinho, mas que ele não dava bola a isso.

Continuou a salientar que quando tinha quinze anos foi para o segundo abrigo, devido a seu perfil, alegando que este trabalha com fortalecimento de autonomia, através de política de portas abertas, uso do celular, computador, acesso à rua sozinho, que não tinha no abrigo anterior. Acredita que tal dinâmica o auxiliou, que no início sentiu um pouco a diferença, pois tinha que andar de ônibus, correr atrás das coisas, mas que acabou sendo positivo, pois hoje ele mora sozinho e lava, passa e cozinha, que de certa forma o fez ficar mais maduro, e com autonomia satisfatória.

Contou ainda que o primeiro abrigo lhe proporcionou fazer aula de música. Participou de orquestras, tocava trombone, e chegou a viajar para os EUA para tocar. No segundo abrigo foi oferecido um curso na OBRA DO SALVADOR, e que por causa desse curso conseguiu seu primeiro emprego como jovem aprendiz em um supermercado. Acrescentou acreditar que se não estivesse na instituição não teria conseguido conquistar o que conquistou, que não estaria hoje trabalhando e terminando o curso de técnico de automação.

Continuou a contar que quando tinha dezesseis anos passou por outro processo de adoção, explicando que a coordenadora da primeira instituição em que morou entrou em contato com ele para informar que uma família estava interessada em adotar seu irmão, um bebê, que chegou depois na instituição, enfatizando que tal contato foi estabelecido com ele, e não com a coordenação do acolhimento que residia na época, expressando satisfação com a questão da autonomia. Desta forma, passou por um período de adaptação com a família, contudo não se sentiu acolhido, não conseguindo estabelecer um diálogo com a família, mencionando que o casal era jovem, tendo em torno de 35 anos e ele entendia que a convivência com um adolescente seria mais difícil que com um bebê, de forma que o casal verbalizou que não poderia adotá-lo, mas esclareceu que ele teria acesso livre para ter contato com o irmão.

Explicitou ainda mais um processo de adoção, contando que foi com um casal homossexual, afirmando não ter preconceito algum, que ele adoraria ter um pai, que pudesse contar, mas que da mesma forma havia muitas regras, justificando que já se sentia uma pessoa autônoma, que tinha sua renda e agia suas coisas, e o "pai" queria lhe impor de somente andar junto, horários, etc. Explicou que seria adotado oficialmente em nome de apenas um dos integrantes da família, mas passou a ter receio do que as pessoas achariam, que a menina que ele ficava na época também ficava questionando o que as pessoas iriam achar, e levantou a possibilidade do adotante estar "dando em cima" do Davi. Devido a tais questões e receios pediu para retornar ao acolhimento, por isso o "pai" ficou com certa "raiva" e chegou a jogar suas coisas em frente ao acolhimento, mas hoje ambos têm contato. Davi contou que ao questioná-lo sobre tal atitude o mesmo respondeu que ficou entristecido pela situação.

Quanto ao funcionamento das instituições disse que não mudaria em nada, que deixaria do jeito como foi "criado", tendo que se esforçar para se recordar de algo negativo, mas lembrou que na primeira instituição foi ameaçado, que quando faziam bagunça ameaçavam "mandá-los" para o DEGASE OU PADRE SEVERINO. Inclusive contou uma situação em que foi acusado de abusar de seu irmão, e que a psicóloga o ameaçou dizendo que se ele não confessasse que cometeu aquele ato ela iria mandá-lo para o Padre Severino, por isso acabou assumindo a culpa, sem ter feito nada, mas que após certo tempo foi revelado o verdadeiro culpado.

Contou ainda uma situação, já na segunda casa de acolhimento, em que uma cuidadora levou uma caixa de biscoitos vencidos, tendo percebido, falou com tal cuidadora, e esta disse que ainda dava para comer, então ele falou com a coordenadora que pediu que ela levasse para casa ou que se desfizesse deles, o que gerou uma situação de tensão, acreditando que até hoje a funcionária não gosta dele. 


\section{Depois da Institucionalização}

Continuou a contar que hoje não tem contato com os cinco irmãos adotados pela família do Rio de Janeiro. Às vezes entra em contato com os pais desses irmãos, que alegam ainda não ser a hora dessa aproximação e que ele entende essa preocupação, pois os irmãos são mais novos e como ele quis voltar, entende que os pais temam que ele os influencie. Contudo, com a irmã que está acolhida, de 17 anos, disse ter contato e a visita sempre, assim como seu sobrinho que está em outra instituição de acolhimento.

Expressou que nunca se sentiu inferior por ter passado pela experiência de abrigo, que acredita que tenha sido bom para ele, que às vezes ele se admira, pois é uma pessoa contente, feliz, mas admitindo sentir falta de um PAI, uma família, não necessariamente a biológica, mas de uma família que o apoiasse. Afirmou que, das famílias pelas quais passou, só se arrepende de não ter valorizado a primeira, pois lá tinha tudo, mesmo com as regras ele sentia que eles lhe davam carinho, atenção e não lhe faltava nada. Já das outras, não se arrepende de ter voltado.

Explicou que quando fez dezoito anos saiu do acolhimento e passou a residir sozinho, que paga aluguel, estuda, trabalha no Ministério Público, e que sonha cursar Direito, pois gostou da área, e acredita estar caminhando para isso. Esse ano termina seu técnico em automação e está feliz com o caminhar das coisas.

\section{Síntese analítica:}

O período antes da institucionalização foi marcado por fragilidades familiares, mais especificamente a violência sexual, motivo do abrigamento de todo grupo de irmãos. O período durante a institucionalização foi marcado pela troca de abrigos, por oportunidades que porporcionaram, desde o inicio, crescimento pessoal, cultural e social, e devido ao trabalho de autonomia feito pela segunda instituição, gerou seu empoderamento. Apesar de experiências frustradas de adoção e outras intercorrências, observou-se que a visão do entrevistado sobre o abrigo continuou sendo positiva. Após o período institucional, mostrou satisfação com o que conquistou, agradecimento pelo que lhe foi proporcionado outrora e perspectivas quanto ao futuro.

\section{DISCUSSÃO}

Diante das histórias de vida relatadas acima, faz-se necessário dividir essa discussão em três momentos: Antes, durante e após a institucionalização. Dessa forma pretende-se analisar e comparar os pontos positivos e negativos diante das percepções de cada entrevistado sobre o acolhimento institucional e suas possíveis consequências futuras.

\section{Antes da institucionalização}

Foi percebido que os entrevistados tiveram em comum os motivos para entrada na instituição de acolhimento, tendo todos eles ido para o abrigo por motivo de violência. No caso da Vitória por falta de condições financeiras foi entregue a instituição por sua genitora, por volta do ano de 1995, com aproximadamente um ano de idade. Já o Gabriel teve os pais assasinados, sofrendo então um abandono por parte dos familiares que, segundo ele, não quiseram criá-lo, tendo ido para o abrigo com dois anos de idade entre os anos de 2000 e 2001. Davi por sua vez, foi institucionalizado junto com outros irmãos devido à situação de violência sexual por parte do genitor com suas irmãs. Sua entrada no abrigo é um pouco mais recente, no ano de 2006, com nove anos de idade.

Ressalta-se que todos os entrevistados foram para o acolhimento institucional na vigência do ECA, Lei $\mathrm{n}^{\mathrm{o}} 8.069 / 1990$. Esta Lei foi um marco nacional, que revolucionou o ordenamento jurídico com quebra de antigos paradigmas e introdução de novos, na proteção e garantia dos direitos infanto-juvenis. Esse estatuto conferiu às crianças e aos adolescentes a posição de sujeito de direito. Em seu artigo $3^{\circ}$ estabelece que: "A 
criança e o adolescente gozam de todos os direitos fundamentais inerentes à pessoa humana, sem prejuízo da proteção integral (...)".

Neste momento é importante destacar o conceito de instituição de acolhimento, segundo o CONANDA (Conselho Nacional dos Direitos da Criança e do Adolescente, 2009):

Serviço que oferece acolhimento provisório para crianças e adolescentes afastados do convívio familiar por meio de medida protetiva de abrigo (ECA, Art. 101), em função de abandono ou cujas famílias ou responsáveis encontrem-se temporariamente impossibilitados de cumprir sua função de cuidado e proteção, até que seja viabilizado o retorno ao convívio com a família de origem ou, na sua impossibilidade, encaminhamento para família substituta (CNAS/CONANDA, 2009, p.63).

De acordo com tal citação pode-se dizer que as instituições que acolheram os entrevistados cumpriram sua função, no que tange ao cuidado e proteção de crianças e adolescentes em situação de vulnerabilidade e risco social.

\section{Durante a institucionalização}

Quanto ao período de institucionalização, ressalta-se que todos os entrevistados relataram mais aspectos positivos do que negativos sobre as instituições. O Davi destacou oportunidades que, ao seu ver, foram muito boas, como, por exemplo, ter se dedicado mais ao estudo dentro da instituição, assim como ter tido a oportunidade de fazer aulas de música, chegando a viajar para o exterior para apresentar-se com a orquestra de Campos. Além disso, destacou o trabalho de incentivo à autonomia quando esteve no segundo abrigo, tendo que pegar ônibus sozinho, acesso a um celular próprio, entre outros. Acredita que esses fatores foram importantes, dizendo que se não estivesse na instituição não teria conseguido conquistar o que conquistou, estando hoje morando sozinho, concluindo um curso técnico e empregado no Ministério Público.

Alguns dos princípios estabelecidos pelas Orientações Técnicas são a "oferta de atendimento personalizado e individualizado" e o "respeito à autonomia da criança, do adolescente e do jovem" (CNAS/ CONANDA, 2009, p.27). A observância desses princípios possibilita a construção da identidade e garante uma melhor autonomia a esses atores sociais, como no caso do Davi.

Cabe ressaltar que a Vitória e o Gabriel viveram em uma mesma instituição de acolhimento e por isso houve muita semelhança em seus discursos. No que diz respeito ao Gabriel, é importante frisar que apesar de ele ter sido adotado pela diretora da instituição, ele permaneceu residindo e viveu como as outras crianças e adolescentes acolhidos, mesmo assim destacou que cada um tinha suas próprias coisas, ressaltando a individualidade, como roupas, objetos pessoais, entre outros, falou também sobre os castigos que a mãe impunha às crianças quando estes faziam bagunça, como, por exemplo, ficar sem acesso a internet, dormir cedo, como também ficar de "cara para a parede" em situações mais graves. Salientou que tais fatores foram positivos para seu crescimento e amadurecimento, verbalizando ser muito agradecido à mãe por tudo que fez, acreditando que foram essas atitudes dela que o fizeram ser quem é hoje. Destacou ainda sobre os passeios na praia, algo que gostava muito.

Já a Vitória comentou que não havia porque reclamar da instituição, pois lá era "tudo certinho", sendo um local onde, segundo ela, "aprendeu tudo". Tinha bons funcionários, não precisava fazer nada, apenas revezava com as meninas para lavar a louça. Ofereciam passeios pela praia e em outros locais durante as férias, bem como oportunidade de estudo até a quarta série dentro da própria instituição e após em uma escola num Município próximo. Também citou os castigos como aspecto positivo, devido às fugas que a mesma percebia como aventuras. 
Assim, pudemos perceber que, predominantemente, aparece uma visão idealizada das educadoras a respeito da família biológica, como se estar junto de pai e mãe fosse um fator de proteção para qualquer tipo de sofrimento e dificuldade, como os únicos capazes de proporcionar tranquilidade, segurança e confiabilidade à criança. (ROSSETTI-FERREIRA; SERRANO; ALMEIDA, 2011, p.330).

Foi possível observar que o Gabriel se referiu ao castigo "ficar de cara para a parede" não como uma situação traumática, mas sim como um auxílio a seu crescimento, já que mostrou-se agradecido à mãe por sua postura de correção quando faziam bagunça, e a Vitória pontuou sobre o revezamento que ocorria em algumas tarefas, como lavar a louça, demonstrando não se incomodar com tal função, já que acreditava que deveria ser assim, pois era uma forma de aprender e contribuir com as tarefas da instituição.

Achamos importante destacar tais visões, para demonstrar que atividades rotineiras fazem parte de um processo natural de desenvolvimento do ser humano, conquanto essas atividades se fazem presentes também em muitos contextos familiares, sendo internalizado pelos entrevistados já citados, como algo natural e importante para seu amadurecimento.

Diante dos relatos também é possível perceber que o respeito com relação à individualidade estava muito presente na instituição. Cada criança tinha a separação dos seus próprios objetos, roupas e outros pertences, como citado. Segundo o CNAS/CONANDA (2009, p.28):

O planejamento do atendimento no serviço deve possibilitar, portanto, espaços que preservem a intimidade e a privacidade, inclusive, o uso de objetos que possibilitem à criança e ao adolescente diferenciar o meu, o seu e o nosso. (...) A organização do ambiente de acolhimento também deverá proporcionar o fortalecimento gradativo da autonomia, de modo condizente com o processo de desenvolvimento e a aquisição de habilidades nas diferentes faixas etárias. (CNAS/CONANDA, 2009, p.28).

É importante destacar que a curiosidade quanto à busca por suas origens e do porquê estavam na instituição, nos casos da Vitória e do Gabriel, se deram por volta dos doze anos de idade, marcando o início da adolescência, época em que esses sujeitos estão em momento bastante conturbado da vida e que se fazem muitos questionamentos em busca de uma identidade.

Erickson (1976) apresentou a adolescência a partir do conceito de moratória, como fase especial no desenvolvimento do sujeito, na qual existe uma confusão de papéis e uma conturbação no que diz respeito a construção de sua identidade, sendo: "um modo de vida entre a infância e a vida adulta" (ERICKSON, 1976, p.128).

Com relação aos aspectos negativos das instituições, nenhum dos entrevistados trouxe queixas ou sugestões de melhoria, contudo o Gabriel ressaltou que gostaria que o nome "orfanato" fosse extinguido, pois contou que percebia o preconceito das pessoas, desde sua infância, que diziam "chegaram as crianças do orfanato, os órfãos" e que tal palavra pesava muito para ele, tendo inclusive, por muitas vezes, mentindo que estava doente para não ter que ir para a escola e escutar tal estigma. Neste momento foi explicado ao Gabriel que tal nomenclatura não deveria ser mais utilizada, apesar da dificuldade das pessoas em entenderem que algumas palavras carregam um peso muito grande, principalmente esta que coloca esses meninos e meninas como abandonados e de certa forma, à deriva, já que legalmente esta não é mais apropriada.

Cabe enfatizar que no século XVIII o Brasil importou da Europa a Roda dos Expostos, uma das mais duradouras instituições de assistência à infância, mantidas pelas Santas Casas de Misericórdia. Nessa época havia muito abandono de crianças nas portas das Igrejas, nas residências e até mesmo pelas ruas. Geralmente eram crianças consideradas ilegítimas ou filhos de escravos, os "menores abandonados", os "órfãos", tendo desta época surgido este estigma, por ter sido uma característica muito marcante no Brasil, mesmo após a publicação do ECA, Lei 8069/1990, ainda é possível escutar tal nomenclatura. 
Outro aspecto que chamou a atenção no discurso dos entrevistados foi a visão negativa do psicólogo dentro da instituição. A Vitória relatou não se lembrar da presença de psicológos na instituição, lembrandose apenas de uma assistente social que conversava e procurava saber os motivos das fugas. Já o Gabriel ressaltou não ter lembranças boas, dizendo que eram muito "chatos" e tinham conversas "horríveis", pois sempre faziam muitas perguntas, mas tinham pouca aproximação pessoal, entendia que o intuito deles era de passar informações ao juíz e os prejudicar.

Destaca-se que dentro da instituição de acolhimento é preciso desenvolver trabalhos em equipe interdisciplinar, cabendo a esses profissionais auxiliar esses sujeitos a enfrentar suas dificuldades e descobrir seus potenciais. Por isso o artigo 92, inciso III, do ECA, adotou como uns dos princípios do acolhimento institucional garantir ao acolhido o direito de ter um atendimento personalizado e em pequenos grupos.

O atendimento psicológico deve compor a atenção psicossocial, que é operacionalizada por um conjunto de procedimentos técnicos especializados, com o objetivo de estruturar ações de atendimento e de proteção a crianças e adolescentes, proporcionando-lhes condições para o fortalecimento da autoestima, o restabelecimento de seu direito à convivência familiar e comunitária em condições dignas de vida e possibilitando a superação da situação de violação de direitos, além da reparação da violência sofrida (CFP, 2009, p.49).

Podemos dar maior destaque ao caso do Davi, pois o mesmo mencionou que além da psicóloga o chamar de "reizinho", acreditando que a coordenadora "passava a mão" em sua cabeça, ainda ameaçava as crianças quando faziam bagunça, mencionando que seriam enviados para o DEGASE OU PADRE SEVERINO, instituições de cumprimento de medidas sócio-educativas. Salientou que certa vez, a psicóloga o acusou de ter abusado de seu irmão e que o ameaçou, dizendo que se este não confessasse iria mandá-lo para o PADRE SEVERINO, tendo ele assumido a culpa por medo. Após certo tempo foi revelado o verdadeiro culpado.

Observa-se nesta conduta uma prática de violência psicológica, utilizando-se de um poder institucional e uma inadequação quanto a ética de sua profissão. A criança e adolescente precisam ser ouvidos, questionados e levados "a sério". No caso de crianças e adolescentes que vão para instituições de acolhimento com o intuito de proteção, por conta de uma situação como a dos entrevistados, acabam passando por outra forma de violência e preconceito.

A Vitória, apesar de ter conhecido sua mãe biológica, e esta ter tentado aproximação algumas vezes, não a via como alguém próxima, com vínculos afetivos formados, era uma pessoa estranha para ela, assim como sua irmã biológica, que residia na mesma instituição. Contudo, a mesma construiu na instituição, vínculos de afinidade, amizade e cumplicidade, mas nenhum deles que referenciasse alguém como sua própria família. Foi com um grupo específico de amigas que a entrevistada iniciou tentativas de fuga da instituição, segundo ela não porque era um local ruim, mas sim porque tinha curiosidade em saber sobre suas origens. Devido a essas inúmeras tentivas de fuga o juíz decidiu dar sua guarda, já na adolescência, de volta para a mãe.

Já o Gabriel, que não teve contato com seus pais biológicos, criou fortes laços afetivos dentro da instituição, pois foi adotado pela diretora, além de ter mais duas cuidadoras às quais também refere como mãe. Citou por diversas vezes que as pessoas de lá eram uma família, porém sofreu e sentiu mais falta de um pai, mesmo tendo tido o marido de sua mãe adotiva como tal, mas não criou laços afetivos com este. Sendo assim, devido ao sentimento de pertencimento ao local, como família, nunca tentou fugir da instituição, ressaltando nunca ter pensado nisso, já que não teria motivos.

O Davi, no momento em que estava na instituição não sentiu esta necessidade de ter uma família, tanto que teve três tentativas de adoção por diferentes famílias e mesmo assim preferiu retornar a instituição. Por ter ido para a instituição com nove anos de idade junto com seus irmãos, com os quais já tinham um laço afetivo estabelecido, sempre tenta manter o contato com estes, demonstrando preocupação com sua família biológica. 
Rossetti-Ferreira; Serrano; Almeida (2011) desenvolveram uma "reflexão sobre o desenvolvimento humano e o contexto institucional". Elas acreditam que todo o contexto institucional, a equipe técnica, os cuidadores, os colegas, o ambiente escolar, enfim, tudo e todos que fazem parte do dia-a-dia desses meninos e meninas vão colaborar expressivamente para a sua construção humana e visão de mundo.

Por isso, essas autoras sugerem como possibilidade de enfrentamento do desafio complexo de trabalhar com crianças e adolescentes institucionalizados a perspectiva da RedSig, ou seja, Rede de Significações. A RedSig vai atentar-se para todos os significados existentes no contexto social daquele grupo específico. Além disso, acredita que o ser humano é um ser em constante construção, aberto para novas perspectivas de vida, conquanto novas significações surjam em sua RedSig.

No referencial da RedSig entende-se que o tornar-se humano é marcado pela imersão permanente do homem em um mundo simbólico e em um processo social contínuo e compulsivo de dar e criar sentidos. Nas interações com os outros e com o mundo, em certo momento e contexto sócio-histórico, a pessoa constrói seus significados, suas relações e a si próprio como sujeito. (ROSSETTI-FERREIRA; SERRANO; ALMEIDA, 2011, p.63).

De acordo com alguns relatos da literatura, pode-se dizer o quanto o abrigamento é negativo, no que tange às relações e vínculos criados com crianças e adolescentes. Ramos (2009) citando Weber (2004) afirma que "a criança institucionalizada está sujeita a uma rotina artificial de relações estereotipadas que fala por ela, privando-a de seu espaço subjetivo, de seus conteúdos individuais e da possibilidade de construção de vínculos afetivos". (RAMOS, 2009, p.85). Contudo, podemos perceber, a partir dos relatos acima que não deve-se generalizar tais pensamentos, já que no caso destes entrevistados houve sim a criação de vínculos afetivos dentro das instituições de acolhimento.

Há também uma compreensão de que o afastamento, a ruptura com os ambientes muito violentos é necessário e benéfico para a criança ou adolescente. Então, o que se coloca em pauta parece ser a ideia de que o melhor para a criança/adolescente não seria nem a instituição, nem a sua família e sim uma família afetuosa, continente, onde se estabelecem relações promotoras de uma vida psíquica saudável. Essa família, no entanto, está no campo ideal, no nosso imaginário, no nosso desejo, tendo pouca relação com as famílias concretas dos acolhidos e mesmo com várias das famílias com quem convivemos no nosso dia a dia. (ROSSETTI-FERREIRA; SERRANO; ALMEIDA, 2011, p.78).

\section{Após a institucionalização}

O período após a institucionalização, no caso da Vitória foi bem intenso, marcado por passagens de violências. Aos 14 anos, após decisão judicial, foi residir com a genitora, período no qual sofreu tentativa de abuso por uma pessoa próxima a família, que motivou sua fuga de casa, decidindo que iria "pra onde a vida me levar". Assim, ao conhecer uma amiga, morou escondida na casa desta, apenas para dormir e comer. Neste período ficou marcado para ela que a avó da amiga a considerava um "molequinho de rua", e ela assim se considerava também. Trabalhou em uma pizzaria, ainda menor de idade, onde não recebia muito, mas recebia alimentação e moradia. Sentiu-se novamente abandonada pela genitora, pois ao sofrer um acidente em que foi gravemente queimada, esta foi ao hospital apenas uma vez e não ficou com ela. Após a procura incessante pelo pai e estabelecimento de relação com o mesmo, sofreu rejeição pela família deste e consequentemente dele, caracterizando novamente sentimento de abandono. Foi vítima de violência sexual por um terceiro, sendo estuprada, um episódio traumático.

A violência estrutural segundo Minayo (2001) é aquela violência de base, capaz de influenciar a condição de vida de crianças e adolescentes a partir de decisões históricas, econômicas e sociais. Tais decisões, por serem de interesses ocultos, acabam sendo naturalizadas e tornam ainda mais vulnerável o crescimento e o desenvolvimento de crianças e adolescentes. Dentro deste tipo de violência ressalta-se a condição social, destacando que a maior expressão desta realidade é representada pela violência da desigualdade social. 
Essa espécie de violência pode ser percebida pelas expressões estigmatizantes como: "meninos e meninas de rua", "meninos e meninas trabalhadores" e as "crianças e adolescentes institucionalizados" (MINAYO, 2001, p.94). É inevitável dizer que um fator comum entre todas essas expressões é a condição social, ou desigualdade social, por enfatizarem situação de miséria extrema em que esses indivíduos vivem, como citado anteriormente. Destacamos dessa forma a fala da avó de sua amiga, chamando-a de "molequinho de rua", e a sua percepção sobre si mesma, que ao relatar tal fato, assim se descreveu. Assim, podemos perceber a introjeção do estigma, percebendo tal atitude como algo natural.

Ressalta-se que, quando destacamos a violência sofrida pela entrevistada no âmbito do trabalho, pois prestava serviços sem garantias de direitos, entendemos que para a mesma não foi assim percebido, conquanto expressava gratidão aos empregadores, acreditando que muito faziam por ela. Contudo, isso não justifica a isenção de tais responsabilidades ou minimiza a violência, configurando-se a partir de interesses ocultos. Devido aos fatores ocultos da violência estrutural, notamos que embora tenha passado pelas diversas violências mencionadas, a única que a entrevistada expressou perceber realmente como violência, foi a sexual, possivelmente devido a seu carater materializado.

Sobre as violências sofridas pelo Gabriel, fica evidenciada no motivo de sua institucionalização. Mas, além desta, outra marcante em sua vida foi o forte preconceito sofrido e o estigma de quem vive institucionalizado, revelando que por muitas vezes foi julgado pela sociedade. Chegou a ouvir que seria um "drogado", que iria "roubar e matar", salientando que a sociedade os percebe como monstros. Confirmou sentir tal violência e afirmou que ele é a prova viva de que as pessoas estão erradas e são preconceituosas, julgam sem saber de sua história. Com relação ao Davi, além da violência intra-familiar, este foi marcado por uma violência psicológica durante a situação de abrigamento decorrente da ameaça de uma psicóloga, como já citado anteriormente.

Segundo Badinter (1985) a maior violência existente é a da própria sociedade, a qual sempre reserva para esses sujeitos um estigma forte e carregado de preconceito. Justamente por acreditar que essas pessoas carregarão consigo, 'problemas', 'defeitos', 'caráter duvidoso', ou qualquer outro exemplo ou marca negativa provinda dos pais e/ou do abandono, e que por isso não "darão em boa coisa".

Cabe ressaltar que há uma diferença na percepção de cada entrevistado no que se refere ao estigma do abrigamento. Para o Davi e a Vitória não houve tanto sentimento de exclusão social pelo fato de terem sido acolhidos. Gabriel, diferentemente, percebeu tal exclusão e sentiu o peso do preconceito, se sentindo estigmatizado. Podemos dizer que essa diferença se dá devido a subjetividade de cada um.

Neste período, a Vitória pôde criar vínculos afetivos com pessoas que ocuparam papéis de referência familiares, como uma "mãe" e uma "irmã", concretizando a ruptura do vínculo com a mãe biológica, pois não aceitou os argumentos desta quanto aos motivos de sua institucionalização. Enfatizou que hoje ela é mãe e faria tudo pela sua filha, por isso tais argumentos da mãe seriam fracos. Verbalizou de forma intensa: "Ela estragou minha vida, assim, pela parte do carinho que eu tinha ela não estragou tanto, ela me privou, mas também pelo que eu vi, não privou tanto".

Sendo assim, percebemos que ao dizer tal frase a Vitória pôde ressignificar o que internalizou de sua relação de abandono com a mãe, pois ao mesmo tempo em que disse que a mesma a privou e estragou sua vida, pôde refletir que não estragou nem privou tanto, pois houve compensações.

Com relação as perspectivas futuras todos os entrevistados demonstraram ter planos, sonhos, objetivos. Os três demonstraram desejo de fazer uma faculdade, todos trabalham, se sustentam e almejam um crescimento pessoal e profissional. Essas histórias de vidas contradizem a afirmação de Ramos (2009): "Percebe-se que a maioria de crianças que cresce nessas instituições sem oportunidade de viver em família, seja ela biológica ou substituta, acaba se tornando um indivíduo sem perspectiva, com condições precárias de vida, envolvendo-se na criminalidade". (RAMOS, 2009, p.87). 
Neste sentido, podemos ressaltar que nem sempre as crianças e adolescentes institucionalizados têm caminhos tão sem perspectivas como descrito pela literatura. $\mathrm{O}$ caso dos entrevistados se diferencia da citação acima.

\section{CONCLUSÕES}

Diante das histórias de vida narradas, observamos que apesar de encontarmos muitas leituras que trazem aspectos negativos acerca da institucionalização, percebemos a importância da não generalização e da desconstrução de um estigma colocado em cima desses sujeitos e dessas instituições. Haja visto que os três entrevistados encaram a realidade institucional, pela qual passaram, como positiva em suas vidas. Além disso, todos verbalizaram sobre perspectivas e metas a serem alcançadas, almejando-as, e inclusive caminhando de forma a alcançá-las.

Observando os discursos, percebemos algumas contradições no que diz respeito a padrões estabelecidos legalmente. Algumas exigências de adequação a parâmetros legais e que são restritivas, foram encaradas pelos entrevistados como normais, rotineiras e positivas, como por exemplo, a quantidade de crianças dentro de uma instituição, que para o Gabriel não era um problema, pelo contrário, sendo algo divertido e no caso da Vitória o auxílio que dava aos serviços domésticos, como lavar a louça.

Cabe enfatizar que tais parâmetros não devem ser desrespeitados, visto que o ECA e o CONANDA muito contribuíram para a humanização do ambiente institucional, bem como sua melhora de forma geral no decorrer do tempo. Por exemplo, o Davi teve a oportunidade de estar em um abrigo com um trabalho voltado para o ganho de autonomia, algo que se encontra como exigência legal, contribuindo para trabalhar sua individualidade e construção da identidade.

Insta mencionar que com apenas três sujeitos de pesquisa, encontramos grande diversidade no que diz respeito a forma de introjetar a experiência institucional. Sendo assim, observamos a importância do respeito à subjetividade e individualidade de cada um, reforçando o preconizado pela legislação vigente.

Podemos ressaltar, assim, a importância do papel do psicólogo nas instituições, já que este é o primeiro que deve respeitar a subjetividade e individualidade dos sujeitos. Seu papel dentro de tais instituições não é de fiscalizar, vigiar, corrigir, nem clinicar. Seu papel é de integrar uma equipe interdisciplinar, auxiliando nas vivências e nas descobertas de seus potenciais, além de objetivar ações de atendimento, proteção a crianças e adolescentes institucionalizados e garantindo o reestabelecimento do direito à convivência familiar e comunitária.

\section{REFERÊNCIAS}

AMIN, Andréa Rodrigues. Dos direitos fundamentais. In: MACIEL, Kátia Regina F. L. Andrade (coord.). Curso de Direito da Criança e do Adolescente: aspectos teóricos e práticos. $5^{\mathrm{a}}$ ed. Rio de Janeiro-RJ: Lumen Juris, 2011.

BADINTER, Elisabeth. Um amor conquistado: Um mito do amor materno. Rio de Janeiro: Nova Fronteira, 1985.

BAPTISTA, Myrian Veras (coord.). Abrigo: comunidade de acolhida e socioeducação. São Paulo: Instituto Camargo Corrêa, 2006.

BRASIL, Constituição da República Federativa do Brasil de 1988 . Disponível em: http://www.planalto.gov.br/ccivil_03/Constituicao/Constitui\%C3\%A7ao.htm. Acesso em 20 abr. 2016.

BRASIL, Estatuto da Criança e Adolescente. Lei federal 8.069. Diário Oficial da União, 1990. Disponível em: http://www.planalto.gov.br/ccivil_03/Leis/L8069.htm. Acesso em 20 abr. 2016. 
CFP; CREPOP. (Org.). Serviço de Proteção Social a Crianças e Adolescentes Vítimas de Violência, Abuso e Exploração Sexual e suas Famílias: referências para a atuação do psicólogo. Brasília: CFP, 2009

CNAS/CONANDA. Orientações Técnicas: Serviços de Acolhimento para Crianças e Adolescentes. $2^{\mathrm{a}}$ ed. Brasília: MDS, 2009.

CONTE, Marta; SILVEIRA, Marília; TOROSSIAN, Sandra Djambolakdjian; MINAYO, Maria Cecília de Souza. Oficinas de história de vida: uma construção metodológica no enlace entre Psicanálise e Saúde Coletiva. Psicologia \& Sociedade, 2014, 26(3), p. 766-778.

ERIKSON, Erik. Identidade, juventude e crise. Rio de Janeiro: Zahar, 1976.

MINAYO. Maria Cecília de Souza. Violência contra crianças e adolescentes: questão social, questão de saúde. Revis. bras. saúde matern. infant., Recife, 1(2): 91-102, maio-ago., 2001.

Presidência da República, Casa Civil. Lei $\mathbf{n}^{\mathbf{0}}$ 12.010, de 3 de agosto de 2009. Disponível em: https://www.planalto.gov.br/ccivil_03/_ato2007-2010/2009/lei/112010.htm. Acesso em: 03 set. 2016.

Presidência da República, Casa Civil. Lei $\mathrm{n}^{\circ} 8.742$ de 1993. LOAS. Disponível em: http:// www.planalto.gov.br/ccivil_03/Leis/L8742.htm. Acesso em: 03 mar. 2016.

Presidência da República, Casa Civil. Lei $\mathrm{n}^{0} 8.242$ de 1991. CONANDA. Disponível em: http:// www.planalto.gov.br/ccivil_03/leis/L8242.htm. Acesso em: 03 mar. 2016.

Presidência da República, Casa Civil. Lei ${ }^{\circ} 6.697$ de 10 de Outubro de 1979. Código de Menores. Disponível em: http://www.planalto.gov.br/ccivil_03/leis/1970-1979/L6697impressao.htm. Acesso em: 08 fev. 2016.

RAMOS, Patrícia Acácio. Acolhimento institucional de crianças e suas consequências. In: PAULO, Beatrice Marinho (Coord.) Psicologia na Prática Jurídica: A criança em foco. Niterói: Impetus, 2009.

ROSSETTI-FERREIRA, Maria Clotilde; SERRANO, Solange Aparecida; ALMEIDA, Ivy Gonçalves de (Org.). O acolhimento institucional na perspectiva da criança. São Paulo: Hucitec, 2011.

SILVA, Aline Pacheco, BARROS, Carolyne Reis; NOGUEIRA, Maria Luísa Magalhães; BARROS, Vanessa Andrade de. "Conte-me sua história": reflexões sobre o método de História de Vida. Mosaico estudos em psicologia: 2007. Vol 1 (1), p. 25-35. ISSN 1982-1913. 